\title{
An Outline of Loans' Trend in Albania
}

\author{
Ariola Kaza \\ European University of Tirana
}

\section{Doi:10.5901/ajis.2016.v5n3s1p40}

\begin{abstract}
The early 2000 's epitomized very low levels of loans in Albania. The combination of imposition of stringent credit ceilings and the high and rising number of non-performing loans caused the commercial banks to have difficulties to meet the soaring demand for credit. Bank of Albania imposed low credit ceilings, artificially lowering the ability of the banks to provide loans despite having healthy deposit reserves. In 2001 the situation changed dramatically however, as a result of the administrative decision to transfer the bad loans from the Savings Bank to the Loan Handling Agency. This led to a changed financial picture overnight and a greatly improved NPL situation, by wiping out most of them as far as the banking sector was concerned. The Albanian economy had a boom in credit growth particularly after 2004, especially in foreign currency lending. It still remained less than what it should have been, due to low ratio of loans, compared to deposits level. The credit crisis of 2008 saw a decrease in lending, and 2009 saw an even greater deterioration. Nowadays supply has tightened, with banks making it more difficult to request loans, and the demand has decreased as well, with businesses reluctant to take on risky investments, indicating a lack of confidence in the Albanian economy and uncertainty about the future, especially in sectors such as construction, that are regarded as highly important to the overall performance of the economy.
\end{abstract}

Keywords: non-performing loans, credit crisis, economy

\section{Introduction}

After having emerged from a 50 year communist regime, Albania started to transform its economy from a largely planned system to a to a market economy. This process together with generous international assistance helped Albania on its way to progress. Because of strong economic growth, Albania's population enjoyed a period of improved finances, and a significant percentage of the population transitioned from poverty to middle class. Poverty declined by half from 19902008. This transformation continues based on its largely untapped potential and opportunities. The financial crisis of 2008 revealed however the inherent flaw of growth based on internal consumption, and highlighted the need to shift to investment and export-led growth (Meka, 2011).

For all this to take place, several changes must occur. There is an urgent need to implement structural reforms to improve competitiveness, productivity and creativity. Industries that help create jobs have to be encouraged. There must be ways to involve whole segments of the population that haven't experienced any improvements. This is a lot of potential left unused that could otherwise fuel a bigger growth now and in the future, as well as contribute to a greater stability politically that comes from having a larger middle-class.

Improvements in regional connectivity would be quite influential as it would make trade and investments much easier, while creating a much bigger market for the local goods. This is especially important because the lion's share of foreign trade of Albania is with its neighboring countries Italy and Greece (Impavido, et al 2012).

The Albanian economy, especially the banking and financial sectors, are still feeling the aftershocks of the 2008 financial crisis. The lack of experience in the banking sector, in conjunction with poor lending and business approach has deteriorated the overall financial climate. It doesn't help that the world economies, especially the financial and banking sectors, are still feeling the pinch of reduced demand and increased competitiveness in the world market. In 15 years the banking industry in Albania moved from a climate of aggressive expansion and growth in an attempt to capture as large a market share as possible, to cope with high NPL levels and darker economic outlook, at least in the short and medium term. The absorption of a big part of the banks' NPL portfolios changed the financial picture overnight, however both banks and the private sector seem reluctant to commit to risky investments. In the absence of alternative funding sources (other than bank loans), Albanian businesses were facing a harsh reality of tightened loaning conditions by all banks during 2009-2011 and even further to 2012 (www.dukagjinicollege.eu). However banks play such a crucial role in regulating and promoting the right businesses and business models that they have an outsized influence in the rest of the economy (Meka 2012). 
Recognizing their importance, the Government of Albania embarked on a encompassing reform focused on fiscal sustainability, trying to stabilize the financial sector. Great attention was paid to the energy infrastructure, stabilization of pension funds and local administration. Ongoing reforms have increased the general population's and especially the business confidence and optimism, nurturing a climate favorable to growth (Shijaku and Ceca 2010). Of special importance are the Law Reform and the Land Reform, as they make sure fair business can prosper and contracts will be respected, removing major obstacles to both foreign and internal investments. Maintaining the momentum is crucial however as a lot depends on it, not less EU integration and increased confidence in finally being on the right path toward political stability and economic progress for all the different layers of the Albanian society.

Reduced demand for credit from the general population has been offset by an increase on the business side, as indicated by a 2.4\% increase from the private sector in the first 2 months of 2016.

Loans in Lek have increased at a steady rate, while loans in foreign currency have shown signs of continued improvement since the end of last year. The annual growth rate of this portfolio remains moderate however at $1.6 \%$, once again indicating ongoing skepticism from the private sector (Ministry of Finance: September 2015).

Even though credit standards have been lowered for certain segments of the society, they remain pretty stringent for most others, thus artificially reducing demand and slowing down the currency flow for the entire economy. Loans to households have grown at a slower rate than expected (at only $4.2 \%$ annual expansion growth), while mortgage loans have remained virtually unchanged from last year. Rates of interest in Lek in the first two months of 2016 increased only slightly as compared to the interest in the last 3 months of 2015. Because of its low volume, it remains volatile and prone to significant changes, when anyone of the banks decides to increase or decrease its rates. In a longer term, they continue to follow a downward trend, even though it is not as fast as that of interest rate on deposits. By client, the reduced interest rate is more noticeable for households. Credit to the private sector has improved during the first quarter of 2016 across all CESEE countries and this increased credit to the private sector is reinforced as well by the positive and solid trend of loans to households in most regional economies.

Credit performance indicated signs of improvement during the second quarter: The bank credit portfolio achieved an average annual growth of 3\%. This improvement occurred mainly because of the expansion of lek credit by $6.4 \%$, while the portfolio of foreign currency credit showed no signs of change from the year before (INSTAT 2016),

However, its annual growth rates are making very slow progress: The stagnant credit growth shows the low demand as well as the tight supply for this particular product. Strengthening the demand and further improving supply for credit is considered as a precondition in order to have solid medium-term and long-term growth in Albania. Hence, implementing the action plan for the treatment of non-performing loans is of crucial importance (Bank of Albania: September 2016). This is where the justice reform will become very useful- it will enable a more transparent legal setting so that the parties can commit in long-term contracts (Shingjergji 2013).

The new available data and different analyses have not revealed any major changes to our medium-term predictions: In this aspect we do expect our economic activities to majorly improve. It is forecasted that the Albanian economy will return to equilibrium by the second half of 2017, which in turn would assume that inflation will return to target in the second half of 2018 (Albanian Banks Association, July 2016).

These forecasts are conditioned by the fact of maintaining the stimulating monetary policy over this period. The monetary stimulus is expected to remain unchanged over 2016. The balance of risks remains at a disadvantage. It is further toughened by, direct or indirect, potential Brexit implications for the economy and financial system in Albania (Bank of Albania: August 2016).

The Bank of Albania judges that the positive trajectory of economic and financial developments will be maintained in the period ahead. In any case, our monetary policy position will be in line with our inflation target and the need to further consolidate all sources of economic growth ("Action Plan", December 2016).

\section{Conclusion}

A multitude of challenges have arisen in the banking system in Albania making it a very fragile sector. There is a plethora of problems caused by the economic crisis as well as by the reduction of income that used to be generated from Albanian emigrants worldwide. Another enormous challenge that is being faced now is the fact that banks hold a high percentage of non-performing loans (NPL). This increasing of NPL-s is attributable mainly to the bad loans that the Albanian banks issued right after post-communist transition.

In the light of the above situation, an examination of how both bank specific and macro-economic determinants affect NPL-s should be done. The following variables are found to have a major significance on the ratio of NPL: Real 
GDP growth, unemployment, inflation, loan interest rates and remittances. Macro-economic conditions are closely linked to the banking performance. Simply put a GDP growth is always found to have a negative relationship with NPL-S. Similarly, interest rates have a direct influence on the lending capacity of the borrower, especially if the change of interest rate is significant.

Bank specific indicators are also found to have a major power on NPL-s. Variables which are specific to the bank (such as size, efficiency etc) market power are also very important determinants because they can cause risky loans.

High ratios of NPL-s continue to have a strong presence in Albania and they present an obstacle in the economic development. Minimizing these NPL-s is necessary to improve our economic growth and efficiency. Therefore it is recommended that banks in Albania look for ways to improve loan procedures and practices, in order to help economy recover faster. They should restructure the loans with new terms or collateral. Additionally it is advised that they issue smaller loans rather than larger ones. In order to get started with reviewing existing policies and procedures- staff training remains a crucial step in achieving this. It's time for banks to lower the risk and go back to recovery.

\section{References}

Action plan for reducing non-performing loans (December 2016) https://www.bankofalbania.org/web/Action_plan_for_reducing_non_ performing_loans_7402_2.php

Albanian Banks (July 2016) Association, http://www.aab.al/al

Bank of Albania: Decisions by the Supervisory Council of the Bank of Albania, (7 September 2016.", Plus Company Updates, Sept 14 2016 Issue

Bank of Albania, (August 2015) http://www.bankofalbania.org. Institute of Statistics of Albania (INSTAT 2016), http://www.instat.gov.al.

Impavido, G., Klingen, C.A., Sun, Y. (2012). "Non-Performing Loans and the Macroeconomy", IMF, March

Institute of Statistics of Albania (INSTAT 2016), http://www.instat.gov.al.

Meka, E. (2011). "Corporate Bonds - A New Way For Financing Corporate In Albania", Economicus, No.7, Uet/Press, Fall, P.32.

Meka, E. \& Meka, S. (2012). "Albanian financial system in front of global \& financial crisis - a new approach to ensure long-term sustainability",

Ministry of Finance (September 2015). http://www.minfin.gov.al.

Shijaku and Ceca (2010). "A model for credit risk in Albania using banks' panel data". Economic policies in SEE: design, performance and challenges, November $53-72$.

Shingjergji, A. (2013). The impact of Macroeconomic Variables on the Non Performing Loans in the Albanian Banking System during 2005-2012. Academic Journal of Interdisciplinary studies, MCSER Publishing- Rome, Italy, 335-339.

The institute for banks and finance, (August 2016) http://institute-bf.com. 